Vol. 10 (4): 587-594 (2020)

\title{
FACTORS AFFECTING MOBILITY OF ZINC IN SOILS OF UKRAINE
}

\author{
Natalia Makarenko", Valeria Bondar ${ }^{1 *}$, Volodymyr Makarenko ${ }^{2}$, Lyudmyla Symochko ${ }^{3,4}$ \\ ${ }^{1 *}$ National University of Life and Environmental Sciences of Ukraine, Heroiv Oborony Str. 15, 03041 Kyiv, Ukraine; \\ ${ }^{2}$ Kyiv Taras Shevchenko National University of Kyiv, Volodymyrska Str. 64/13, 01601, Kyiv, Ukraine; \\ ${ }^{3}$ Uzhhorod National University, Voloshyna Str. 32, 88000, Uzhhorod, Ukraine; \\ ${ }^{4}$ Institute of Agroecology and Environmental Management, Metrologichna Str. 12, 03143, Kyiv, Ukraine;
}

*Corresponding Author Valeria Bondar, e-mail address: lera_bond@email.ua;

Received July 2020; Accepted August 2020; Published September 2020;

DOI: https://doi.org/10.31407/ijees10.402

\begin{abstract}
Zinc (Zn) deficiency is the most common problem of micronutrient deficiency on our planet. This problem is also relevant for Ukraine, as soils are insufficiently provided with $\mathrm{Zn}$, plants are deficient, respectively, and insufficient quantity of $\mathrm{Zn}$ is contained in food, which leads to human diseases. Our research showed that the total zinc content in soils increased from the north to the south of Ukraine (Polissya $<$ Forest-Steppe $<$ Steppe): in sod-podzolic soil the $\mathrm{Zn}$ content was $40 \mathrm{mg} \mathrm{kg}^{-1}$, in dark gray podzolic - $45 \mathrm{mg} \mathrm{kg}^{-1}$, chernozem typical - $48 \mathrm{mg} \mathrm{kg}^{-1}$, chernozem ordinary - $58 \mathrm{mg} \mathrm{kg}^{-1}$, dark chestnut $-70 \mathrm{mg}$ $\mathrm{kg}^{-1}$. The content of $\mathrm{Zn}$ mobile forms, on the contrary, was subject to inverse dependence - the highest level was observed in the soils of Polissya $-9.5 \mathrm{mg} \mathrm{kg}^{-1}$, the lowest in the soils of Steppe $-0.5 \mathrm{mg} \mathrm{kg}^{-1}$. Zn was more firmly fixed by the soils of chernozem-type, higher mobility was observed in soils with pronounced podzolic processes. $\mathrm{Zn}$ mobility depended from the properties of soil: $\mathrm{pH}$ of the soil solution, the amount of organic matter and clay minerals. Zn mobility increased with increasing soil acidity, increasing the amount of organic matter and clay fraction. There was a close inverse correlation between these indicators and $\mathrm{Zn}$ mobility: the pairwise correlation coefficients (r) ranged from - 0.861 to - 0.991. Agrotechnological methods of winter wheat growing reduced the quantity of potentially mobile $\mathrm{Zn}$ compounds in the soils of Polissya, Forest-Steppe and Steppe of Ukraine in compared to the natural background. However, mineral and organic fertilizers mainly increased their content, as well as intensified the transfer of $\mathrm{Zn}$ from the soil to wheat plants, as evidenced by the biological absorption coefficients which were $>1$.
\end{abstract}

Keywords: agrochemical parameters, mobility, soil, climatic zones, zinc. 